\title{
Supergene minerals in the Horní Slavkov uranium ore district, Czech Republic
}

\author{
Supergenní minerály uranového rudního revíru Horní Slavkov, \\ Česká republika
}

\author{
(9 figs, 7 tabs) \\ JAKUB PLÁŠIL ${ }^{1}$ - JIŘÍ SEJKORA² - PETR ONDRUŠ ${ }^{3}$ - FRANTIŠEK VESELOVSKÝ4 - PAVEL BERAN $^{5}$ - VIKTOR GOLIÁŠ ${ }^{1}$ \\ ${ }^{1}$ Institute of Geochemistry, Mineralogy and Mineral Resources, Faculty of Science, Charles University, Albertov 6, CZ-128 43, Praha 2, \\ Czech Republic \\ 2 Department of Mineralogy and Petrology, National Museum, Václavské nám. 68, CZ-115 79 Praha 1, Czech Republic \\ ${ }^{3}$ Biskupský dvior 2, CZ-110 00 Praha 1, Czech Republic \\ ${ }^{4}$ Czech Geological Survey, Klárov 3, CZ-118 21 Praha 1, Czech Republic \\ ${ }^{5}$ Regional Museum Sokolov, Zámecká 1, Sokolov, CZ-356 00, Czech Republic
}

\begin{abstract}
This paper presents the existing and newly obtained information on supergene minerals of the Horní Slavkov uranium ore district. Mineralogical studies confirmed occurrences of the following minerals: anglesite, annabergite, arsenolite, autunite, carnotite, compreignacite, cuprosklodowskite, kaatialaite, liebigite, meta-autunite, metanováčekite, metatorbernite, mohrite, nováčekite, phosphuranylite, rutherfordine, schultenite, siderite, torbernite, uranophane, zeunerite, and unnamed phase UNK5. The present study did not confirm the presence of previously reported occurrences of bassetite, soddyite, uranophane- $\beta$ and uranospinite. Also presented is interpretation of formation of the supergene mineralization in this ore district.
\end{abstract}

Key words: Horní Slavkov uranium district; supergene minerals; uranium; uranyl minerals

\section{Review of geological conditions of the Horní Slavkov uranium district}

The uranium ore accumulations around Horní Slavkov are tied to an isolated roof pendant of metamorphic rocks in the southern part of the Karlovy Vary granite pluton (Komínek et al. 1994). The mineralization concentrated in the Horní Slavkov ore district comprises the following deposits and vein clusters: Barbora, Ležnice, Zdař Bůh, Pichtova hora, Svatopluk, Bošírany, Nadlesí, Krásná, Vlčí, Čistá and Teplička - Hlinky.

The complex of metamorphic rocks constituting the isolated roof pendant is $400-700 \mathrm{~m}$ thick in the central part and 150-200 $\mathrm{m}$ in the northern and western parts. Coarse-grained orthogneiss and a paragneiss unit, including amphibolites, quartzites and calc-silicate gneisses, in addition to predominating paragneisses, are the main rock types. Paragneisses are strongly migmatized at contact with orthogneiss. The Variscan granite pluton below the roof pendant includes two main granite types: the older biotite granite of the "Horský" type (Older intrusive complex - OIC) and younger autometamorphic granite of the "Krušnohorský" type (Younger intrusive complex - YIC). The YIC granites, including greisenized parts, occur mainly in the western part of the ore district. The metamorphic roof pendant is penetrated by aplite, aplitic granite and diorite. The uranium mineralization is nearly exclusively bound to paragneisses and amphibolites, while orthogneiss and migmatized or silicified paragneisses show a negative correlation with mineralization.

Metamorphic rocks are folded in several complicated antiforms on axis trending East-West, with flanks dipping 60 to $80^{\circ}$. The ore district is dissected by a set of parallel faults trending NW-SE (e.g., Southern fault, Bošíra- ny fault) to a group of mutually displaced segments. The Teplá fault, trending NNE-SSW, bounds the district at the East. The uranium mineralization occurs in veins trending NW-SE, 5-20 cm wide, or rarely up to $2 \mathrm{~m}$ wide. These veins form complicated vein clusters at intersection with the NW-SE faults. Veins trending East-West and North-South are of minor importance.

The ore is concentrated in lenses a few $\mathrm{mm}$ to several $\mathrm{dm}$ wide, but a width of 1 to $5 \mathrm{~cm}$ was typical. The size of the surface of lenses varied from a fraction of $\mathrm{m}^{2}$ to hundreds of $\mathrm{m}^{2}$, exceptionally up to $2500 \mathrm{~m}^{2}$. The mineralization was present from land surface to a maximum depth of $450 \mathrm{~m}$ (vein cluster Ležnice and Svatopluk). The veins did not continue in the underlying granite (Veselý 1986).

The vein filling rather varied throughout the district. The oldest $\mathrm{Sn}-\mathrm{W}$ mineralization was confined to a separate vein system with veins trending NE-SW and dipping $60-70^{\circ}$ to the NW. Mineralization in veins carrying uranium took place in several stages:

- quartz-fluorite stage (quartz, fluorite, pyrite, arsenopyrite, marcasite),

- carbonate stage (carbonates),

- uraninite-sulfide stage (older generation uraninite, carbonates, sulfides of $\mathrm{Zn}, \mathrm{Cu}, \mathrm{Pb}$ ),

- arsenide stage (younger generation uraninite, complex ores of $\mathrm{Co}, \mathrm{Ni}, \mathrm{Bi}, \mathrm{Ag}$, As, quartz, carbonates).

The uranium mineralization is represented by dominating uraninite, but also by uranium powdery aggregates, ningoyite (Dymkov et al. 1986) and at places by supergene uranium minerals. The age of uranium mineralization has been determined at 258 to $254 \mathrm{Ma}$.

The first significant occurrence of uranium minerals was found in 1946 in the Zdař Bůh vein by surface radiometry survey. Complex prospecting and exploration 
works were conducted during the period 1946-1962 and exploitation during the years 1948-1962 (Beran et al. 2001, Tomíček 2000). During a short period, 26 shafts and 30 galleries were excavated in a relatively small ore district (Fig. 1). Altogether, underground works include $5082 \mathrm{~m}$ of shafts (Figs 2 and 3), $134979 \mathrm{~m}$ of cross drifts and $227739 \mathrm{~m}$ of adits or galleries following veins. Exploration and subsequent mining included 111 veins with uranium mineralization considered as economic by the then valid standards.

Altogether, $3159212 \mathrm{~m}^{2}$ of vein area were exploited. The operation yielded 2668 tons of uranium (including

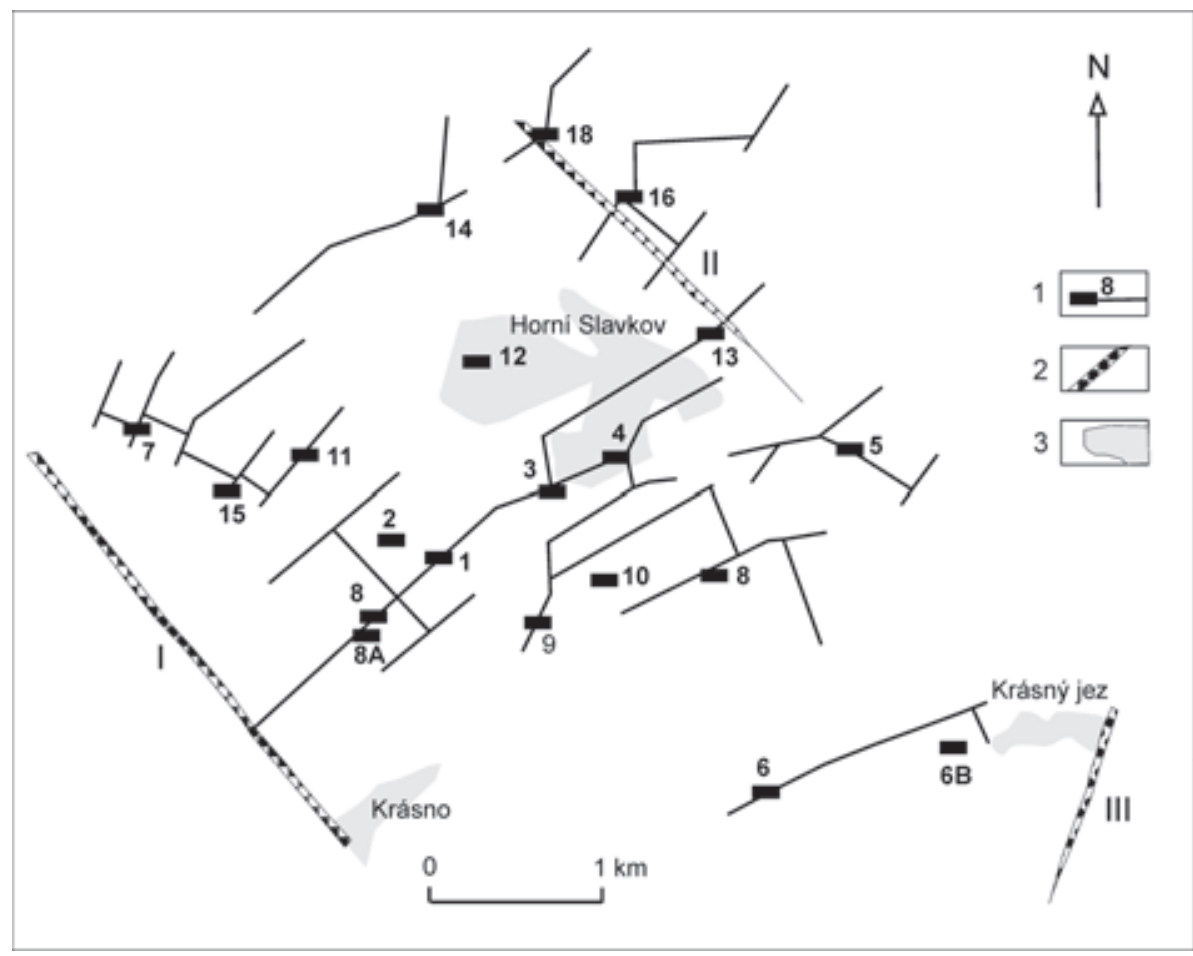

Fig. 1 Location of mine works in the Horní Slavkov uranium district and directions of the main exploitation drives in the interval of 500 to $550 \mathrm{~m}$ a.s.1. (according to Veselý 1988 in Beran et al. 2001).

Explanation: 1 - underground works and directions of exploitation drives; 2 - main faults: I - southern fault, II - Bošírany fault, III - Teplá fault; 3 - contours of settlements.

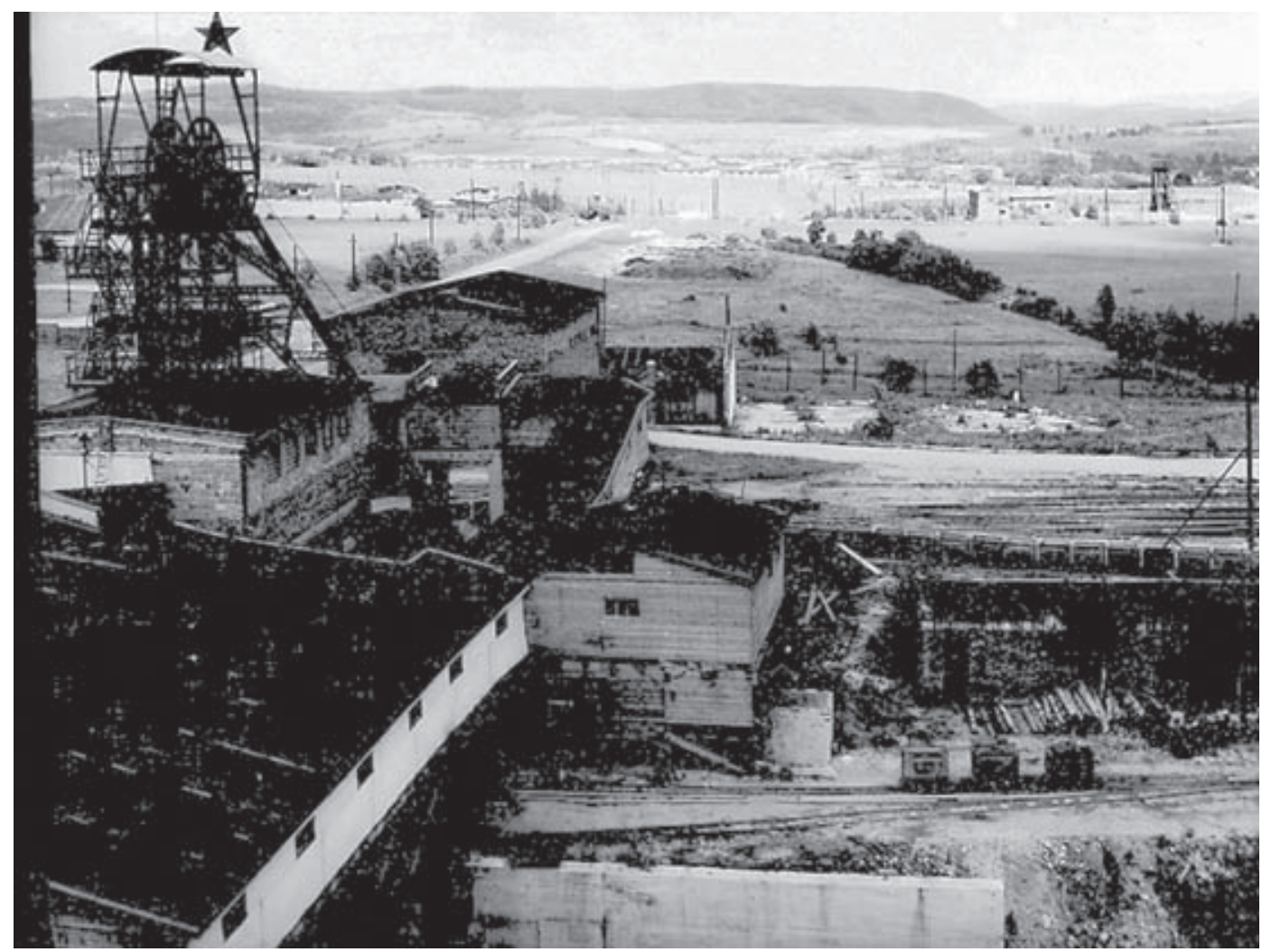

Fig. 2 Shaft tower No. 8 in the Horní Slavkov uranium district; shaft tower No. 1 is seen on the right in the background (1960, Archive of Pentar s.r.o., Horní Slavkov) 
Fig. 3 Dumps and shaft towers No. 8 in the Horní Slavkov uranium district; in the foreground central workshop of the mines (1960, Archive of Pentar s.r.o., Horní Slavkov).

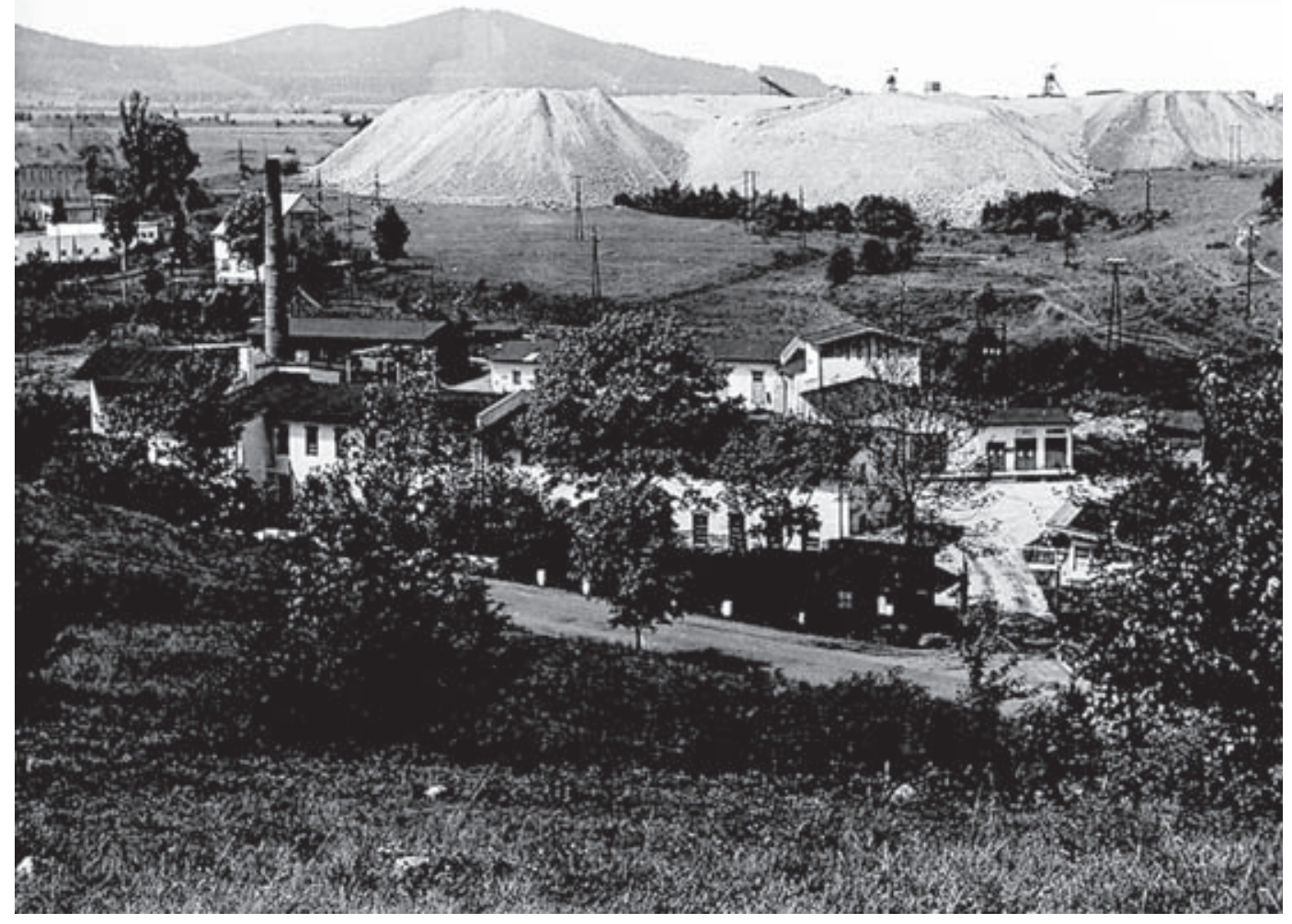

loss in the process of exploitation). Significant shares in uranium mining relate to the vein cluster Barbora (779 t U), Ležnice (651 t U), Zdař Bůh (539 t U), Pichtova hora (208 t U), Svatopluk (201 t U) and Bošíŕany (181 t U). However, the allocation of workforce (prisoners of war during the first stage, followed by political prisoners), the intensity of mining operations, and the allocated investment were absolutely out of proportion to the size of the ore district and ore reserves. The mining activities in the Horní Slavkov district resulted in considerable changes of the natural land surface due to numerous dumps (Fig. 4) and caved-in areas, devastation of natural drainage system, including destruction of historic ponds serving during past centuries as water source for mining operations.

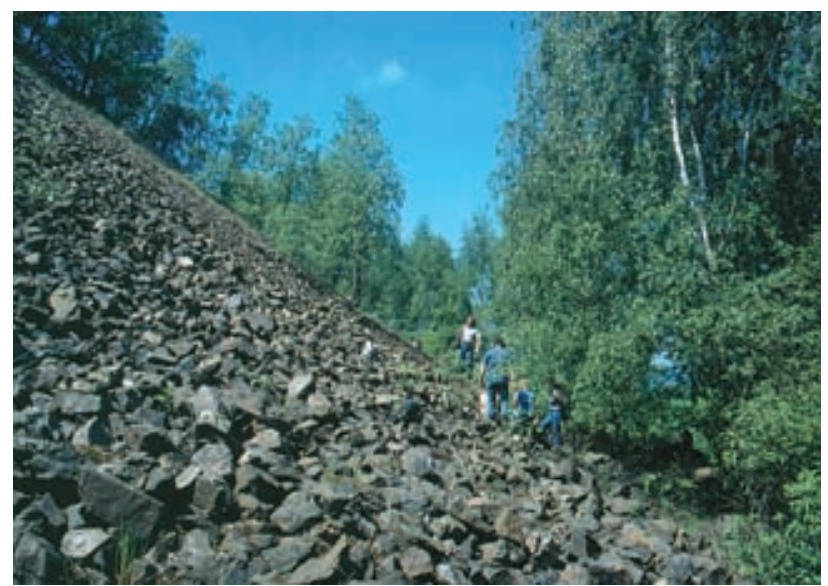

Fig. 4 Dump of the mine No. 11, Horní Slavkov uranium district (photograph by J. Sejkora, May 2002).

\section{Supergene mineralization in the Horní Slavkov uranium ore district}

Information on the supergene mineralization in the district is rather limited. Besides the unpublished work of Dubinkina (1947), we are confined to scarce material from remains of dumps and some specimens preserved in the mineralogical collections of the National Museum (NMCR), Prague, Czech Republic, and Muséum National d'Histoire Naturelle (Museum Paris), Paris, France.

According to Dubinkina (1947), all studied supergene minerals are localized in a strongly developed cementation zone in near-surface parts of the uranium deposit, in particular in a horizon 15 to $50 \mathrm{~m}$ from the surface. In the Zdař Bůh and Barbora vein clusters, uraninite is partly or completely altered to closer undefined black earthy uranium oxides (compact or powdery aggregates of hydrated oxides of $U^{I V}$ and $U^{\mathrm{VI}}$ ) or to compact zones of amorphous $\mathrm{Pb}-\mathrm{U}$ hydroxides ("gummite-type" mineral phases). The cores of the aggregates of black uranium oxides are coated by partly decomposed marcasite and other primary minerals ( $\mathrm{Cu}, \mathrm{Fe}$ sulphides). "Limonite", representing the predominant material of weathered vein, is the final product of decomposition. Minerals of the uranyl arsenate and phosphate associations rim the surface parts of accumulations of black U-oxides. In the Barbora vein cluster, 18 to $50 \mathrm{~m}$ below surface, a mineral assemblage of uranyl silicates occurred. These minerals intensively replaced weathered uraninite and were in turn replaced by uranyl phosphates and arsenates (Dubinkina 1947). 


\section{Methods of study}

If not stated otherwise, all minerals described in this report have been identified by X-ray powder diffraction analysis (XRD). Powder diffraction data were collected using two instruments:

1) Philips X'Pert MPD diffractometer (Czech Geological Survey, Prague) - a metallo-ceramic copper tube was operated at high-voltage of $40 \mathrm{kV}$ and tube current of 40 $\mathrm{mA}$. A graphite secondary monochromator has been used

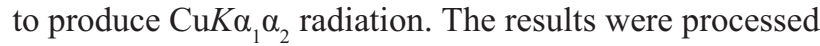
using X-ray analysis software ZDS for DOS (Ondruš 1993), Bede ZDS Search/Match ver. 4.5 (Ondruš - Skála 1997)

2) PANalytical $X^{\prime}$ Pert Pro diffractometer (Faculty of Science, Charles University, Prague) with X'Celerator detector, with secondary monochromator, using $\mathrm{CuK} \alpha$ radiation at $40 \mathrm{kV}$ and $30 \mathrm{~mA}$. Measured data were processed using software High Score Plus 2.0.1 (PANalytical). Le Baile fit (Pseudo-Voigt profile function) was used for refinement of unit- cell parameters, and in some cases the program by Burnham (1962).

Energy dispersion analyzer LinkISIS300 with the microscope CamScan4 was used for semiquantitative chemical composition data (operator R. Procházka, Faculty of Science, Charles University, Prague), using natural (not polished) surfaces of minerals. The surface morphology of samples was studied with the optical microscope Nikon SMZ1500 in combination with the digital camera Nikon DXM1200F, for photography in incandescent light. Detailes of surface morphology were studied in secondary electron images using the Jeol JSM-6380 scanning electron microscopy (operators M. Mazuch and J. Plášil, Faculty of Science, Charles University, Prague).

\section{Review of identified minerals}

\section{Anglesite $\mathrm{PbSO}_{4}$}

Anglesite has been found in samples from partly weathered galena vein with veinlets and inclusions of other primary minerals, mainly marcasite, pyrite and arsenopyrite. This material was collected at the shaft No. 8. Anglesite occurs as sub-recently formed, bluish earthy or botryoidal aggregates several $\mathrm{cm}^{2}$ in size. It occurs in association with mohrite, kaatialaite, schultenite, and secondary siderite. Anglesite is identified by XRD as it occurs in mixtures with other minerals.

\section{Annabergite $\mathrm{Ni}_{3}\left(\mathrm{AsO}_{4}\right)_{2} .8 \mathrm{H}_{2} \mathrm{O}$}

It has been found on partly weathered samples of vein with galena, carrying veinlets and inclusions of native arsenic and nickelskutterudite. These samples originate from the shaft No. 8. Annabergite occurs in mixture with arsenolite as light green glassy spheroidal aggregates to $1 \mathrm{~mm}$, covering area about $10 \mathrm{~cm}^{2}$. Annabergite is identified by XRD as it occurs in mixtures with other minerals.

\section{Arsenolite $\mathrm{As}_{2} \mathrm{O}_{3}$}

Arsenolite has been identified in samples from a partly weathered vein with galena, veinlets and inclusions of native arsenic, and nickelskutterudite from the shaft No. 8. Arsenolite in mixture with annabergite forms white green glassy spheroidal aggregates to $1 \mathrm{~mm}$, covering surface $10 \mathrm{~cm}^{2}$ in size. Arsenolite is identified by XRD as it occurs in a mixture with annabergite.

\section{Autunite $\mathrm{Ca}\left[\left(\mathrm{UO}_{2}\right)\left(\mathrm{PO}_{4}\right)\right]_{2} \cdot 10-12 \mathrm{H}_{2} \mathrm{O}$ and meta- autunite $\mathrm{Ca}\left[\left(\mathrm{UO}_{2}\right)\left(\mathrm{PO}_{4}\right)\right]_{2} \cdot 2-6 \mathrm{H}_{2} \mathrm{O}$}

Dubinkina (1947) described autunite from near-surface parts of the Zdař Bủh uranium vein, encountered during sinking the shafts Nos 1 and 2. It was associated with bassetite and torbernite. Dubinkina (1947) gave optical values, which differ from those normal for autunite and may possibly indicate presence of meta-autunite. Also, Dubinkina (1947) described from the Barbora vein system an occurrence of often strongly corroded minute tabular autunite crystals on limonitized vein. This type of autunite contains significant As, possibly owing to isomorphous substitution by uranospinite.

In the course of new study autunite has been confirmed in intimate intergrowth with meta-autunite and metatorbernite, and phosphuranylite in yellow-green crystalline aggregates to $2 \mathrm{~mm}$. The aggregates consist of very small tabular crystals. These aggregates are coating strongly weathered vein material. Autunite and meta-autunite are present in much smaller amounts than $\mathrm{Cu}$-dominated member - metatorbernite. Meta-autunite probably formed by recent dehydration of autunite. Autunite in intimate intergrowth with meta-autunite and metatorbernite has been identified by XRD and by semiquantitative chemical spot analyses, indicating prevalence of $\mathrm{Ca}, \mathrm{U}$ and $\mathrm{P}$.

\section{Bassetite $\mathrm{Fe}\left[\left(\mathrm{UO}_{2}\right)\left(\mathrm{PO}_{4}\right)\right]_{2} \cdot 8 \mathrm{H}_{2} \mathrm{O}$}

Dubinkina (1947) described this mineral from near-surface parts of the cementation zone of uranium veins, about 40 to $50 \mathrm{~m}$ below surface. Samples were collected during sinking shafts Nos 1 and 2 on the vein Zdař Bůh. Bassetite occurs in association with autunite and torbernite on "black uranium oxides", resulting from alteration of uraninite. This mineral assemblage is tied to partly limonitized marcasite or other sulphides. Bassetite is younger than autunite and forms rims around crystalline aggregates of autunite. Dubinkina (1947) noted, without closer explanation, that optical properties of local bassetite differ from published values. New study did not confirm the presence of bassetite at the locality.

\section{Carnotite $\mathrm{K}_{2}\left(\mathrm{UO}_{2}\right)_{2} \mathrm{~V}_{2} \mathrm{O}_{8} \cdot 3 \mathrm{H}_{2} \mathrm{O}$}

Carnotite has been found as a very probable component of polymineral aggregates of supergene uranium minerals in several museum specimens (MuseumParis). Yellow, 
very fine-grained aggregates up to $1 \mathrm{~cm}$ across are at places intergrown by small green tabular metatorbernite crystals and deposited on gangue affected by supergene alteration. According to XRD data, the aggregates consist of a mixture of metatorbernite, carnotite and at least one additional phase (8.99 $\AA / 100)$, which has not been identified with certainty, owing to co-incidences in the pattern. As a result of this situation, unit-cell parameters of carnotite have not been refined. Examination of chemical composition of the aggregates confirmed the presence of $\mathrm{Cu}, \mathrm{U}$ and $\mathrm{P}$ (metatorbernite), finer-grained domains contain mainly $\mathrm{V}, \mathrm{U}$ and probable $\mathrm{K}$ (with a strong coincidence of $\mathrm{K}$ and $\mathrm{U}$ in the ED spectrum).

\section{Compreignacite $\mathrm{K}_{2}\left[\left(\mathrm{UO}_{2}\right) \mathrm{O}_{2}(\mathrm{OH})_{3}\right]_{2} \cdot 7 \mathrm{H}_{2} \mathrm{O}$}

This mineral has been identified in several museum specimens carrying original labels with designation "uranospinite" (NMCR) or "fritzscheite" (Museum Paris). Transparent to non-transparent, bright orange platy crystals of compreignacite (Fig. 5), up to $0.5 \mathrm{~mm}$ long, compose orange yellow aggregates covering surface up to several $\mathrm{cm}^{2}$ large. Relatively rare are brown semi-spherical aggregates with a glassy lustre. Compreignacite is sometimes accompanied by compact massive yellow uranophane (powdery at places), green crystalline aggregates of metatorbernite or light green coatings of cuprosklodowskite and crystalline aggregates of zeunerite. Unit-

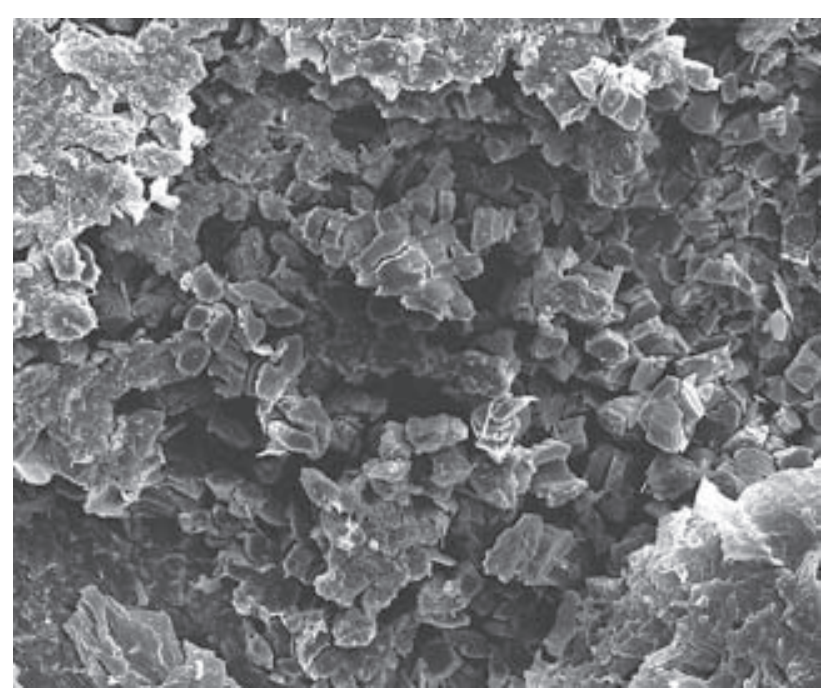

Fig. 5 Tabular crystals of compreignacite, Horní Slavkov uranium district. Width of the area shown is $80 \mu \mathrm{m}$. SEM photograph by J. Plášil.

Table 1 Unit-cell parameters of compreignacite (orthorhombic Pnnm)

\begin{tabular}{|l|cr|}
\hline & this paper & Burns (1998) \\
\hline $\mathrm{a}[\AA]$ & $14.868(1)$ & $14.8591(7)$ \\
$\mathrm{b}[\AA]$ & $7.2036(8)$ & $7.1747(3)$ \\
$\mathrm{c}[\AA]$ & $12.161(2)$ & $12.1871(5)$ \\
$\mathrm{V}\left[\AA^{3}\right]$ & 1302.5 & $1299.3(2)$ \\
\hline
\end{tabular}

cell parameters obtained on compreignacite from Horní Slavkov show good correspondence with data published for this species (Table 1). In view of similarity of XRD data for compreignacite (K-uranyl oxide hydrate), bequerelite (Ca-uranyl oxide hydrate) and billietite (Ba-uranyl oxide hydrate), presence of $\mathrm{Ca}$ and $\mathrm{Ba}$ was checked, with negative result. The relatively low content of $\mathrm{K}$, in combination with relatively high $\mathrm{U}$, cannot be proved due to coincidence in energy dispersion analysis.

\section{Cuprosklodowskite $\mathrm{Cu}\left[\left(\mathrm{UO}_{2}\right)_{2}\left(\mathrm{SiO}_{3} \mathrm{OH}\right)_{2}\right] \cdot 6 \mathrm{H}_{2} \mathrm{O}$}

Dubinkina (1947) described this mineral from the vein system Barbora, intersected in the shaft No. 21 at a depth of about $18 \mathrm{~m}$ and in the shaft No. 37 at a depth of 46 $\mathrm{m}$. Cuprosklodowskite constitutes green earthy aggregates in association with soddyite, zeunerite and uranospinite. A mixture of these minerals is deposited directly on weathered uraninite or it forms a fill in weathered veins, together with "limonite”.

In the course of this study cuprosklodowskite was found in one museum specimen originally designated "fritzscheite" (MuseumParis). It forms small coatings, in part botryoidal, showing variable whitish green colour. The mineral is associated with crystalline aggregates of orange yellow to brown compreignacite and green, powdery to finely crystalline aggregates of zeunerite. Unitcell parameters (Table 2) are in good agreement with data published for cuprosklodowskite. The lower precision of data for cuprosklodowskite from Horní Slavkov is caused by imperfect crystalline state of the mineral (as indicated by broadened diffraction maxima and absence of some diffractions with a low intensity) and minority admixture, which could not be identified.

Table 2 Unit-cell parameters of cuprosklodowskite (triclinic $P$-1)

\begin{tabular}{|l|cc|}
\hline & this paper & Rosenzweig - Ryan (1975) \\
\hline $\mathrm{a}[\AA]$ & $7.06(1)$ & $7.052(5)$ \\
$\mathrm{b}[\AA]$ & $9.19(1)$ & $9.267(8)$ \\
$\mathrm{c}[\AA]$ & $6.675(7)$ & $6.655(5)$ \\
$\alpha\left[^{\circ}\right]$ & $109.54(8)$ & $190.23(5)$ \\
$\beta\left[^{\circ}\right]$ & $90.24(8)$ & $89.84(5)$ \\
$\gamma\left[^{\circ}\right]$ & $108.9(1)$ & $110.01(7)$ \\
$\mathrm{V}\left[\AA^{3}\right]$ & $384(1)$ & 382.9 \\
\hline
\end{tabular}

\section{Kaatialaite $\mathrm{Fe}\left(\mathrm{AsO}_{2}(\mathrm{OH})_{2}\right)_{3} \cdot 5.25 \mathrm{H}_{2} \mathrm{O}$}

This mineral has been found in samples from weathered vein with galena and veinlets or inclusions of marcasite, pyrite and arsenopyrite from the shaft No. 8. Kaatialaite forms white or light blue earthy aggregates or coatings several $\mathrm{cm}^{2}$ in size. It occurs in mixture with mohrite and in association with anglesite, schultenite and secondary siderite. Owing to the presence of other minerals in the mixture, the mineral is identified only by the XRD method. 


\section{Liebigite $\mathrm{Ca}_{2}\left[\left(\mathrm{UO}_{2}\right)\left(\mathrm{CO}_{3}\right)_{3}\right] \cdot 11 \mathrm{H}_{2} \mathrm{O}$}

Liebigite has been found as coatings and crusts, up to $1.5 \mathrm{~mm}$ thick, over areas several $\mathrm{cm}^{2}$ in size (Fig. 6), on slightly weathered uraninite with grey inclusions of copper sulfide. The crusts typically show yellow green colour, characteristic for this mineral. Locally observed coatings with fractured surface and a distinct orange shade are also identified as liebigite, which, however, has a lower crystallinity. Some aggregates with poor coherence, locally observed in the specimen, probably belong to an amorphous phase.

The refined unit-cell parameters of yellow green liebigite closely correspond to the published data (Table 3). The somewhat smaller unit-cell volumes are probably due to a lower crystallinity of mineral aggregates, as indicated by somewhat increased FWHM half-width of individual diffraction maxima. The semiquantitative chemical study of liebigite from Horní Slavkov indicated only $\mathrm{Ca}$ and $\mathrm{U}$ as the essential elements.

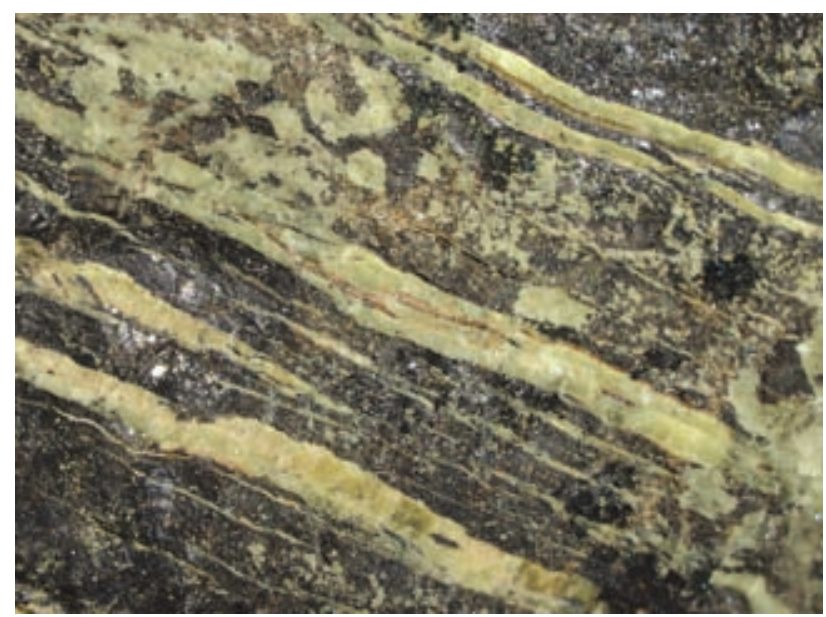

Fig. 6 Yellow green crusts of liebigite on slightly weathered uraninite; Horní Slavkov uranium district. Width of the area shown $8 \mathrm{~mm}$. Nicon SMZ1500 microphotography by J. \& E. Sejkora.

Table 3 Unit-cell parameters of liebigite (orthorhombic Ama2)

\begin{tabular}{|l|cc|}
\hline & this paper & Mereiter $(1982)$ \\
\hline $\mathrm{a}[\AA]$ & $16.682(6)$ & $16.699(3)$ \\
$\mathrm{b}[\AA]$ & $17.59(1)$ & $17.557(3)$ \\
$\mathrm{c}[\AA]$ & $13.652(7)$ & $13.697(3)$ \\
$\mathrm{V}\left[\AA^{3}\right]$ & 4006.9 & 4015.7 \\
\hline
\end{tabular}

\section{Meta-autunite $\mathrm{Ca}\left[\left(\mathrm{UO}_{2}\right)\left(\mathrm{PO}_{4}\right)\right]_{2} \cdot 2-6 \mathrm{H}_{2} \mathrm{O}$}

See autunite and meta-autunite.

$$
\text { Metanováčekite } \mathrm{Mg}\left[\left(\mathrm{UO}_{2}\right)\left(\mathrm{AsO}_{4}\right)\right]_{2} \cdot 4-8 \mathrm{H}_{2} \mathrm{O}
$$

See nováčekite and metanováčekite.

$$
\text { Metatorbernite } \mathrm{Cu}\left[\left(\mathrm{UO}_{2}\right)\left(\mathrm{PO}_{4}\right)\right]_{2} \cdot 8 \mathrm{H}_{2} \mathrm{O}
$$

See torbernite and metatorbernite.

$$
\text { Mohrite }\left(\mathrm{NH}_{4}\right)_{2} \mathrm{Fe}\left(\mathrm{SO}_{4}\right)_{2} \cdot 6 \mathrm{H}_{2} \mathrm{O}
$$

This mineral has been found in a mixture with kaatialaite (see information on kaatialaite) in samples from the shaft No. 8, in association with anglesite, schultenite and secondary siderite. Owing to the presence of other minerals in the mixture, the mineral is identified only by XRD.

\section{Nováčekite $\mathrm{Mg}\left[\left(\mathrm{UO}_{2}\right)\left(\mathrm{AsO}_{4}\right)\right]_{2} \cdot \mathbf{1 0 H}_{2} \mathrm{O} /$ Metanováčekite $\mathrm{Mg}\left[\left(\mathrm{UO}_{2}\right)\left(\mathrm{AsO}_{4}\right)\right]_{2} \cdot 4-8 \mathrm{H}_{2} \mathrm{O}$}

Nováčekite forms small crystalline aggregates of a light beige yellow colour, composed of very thin tabular crystals to $50 \mu \mathrm{m}$ long. Individual crystals show distinct zoning in colour and composition - from light yellow (nováčekite) to a bright emerald green (zeunerite). These aggregates form coatings and veils covering gangue composed of strongly hydrated uraninite and amorphous products of its alteration. The study of samples with powder XRD method indicates that nováčekite (with metanováčekite admixture) is always accompanied by other phases such as zeunerite and uranophane. Microprobe spot analyses of aggregates used for XRD analyses confirmed $U$ and As contents, indicative of nováčekite. The probable presence of $\mathrm{Mg}$ is not safely confirmed because of coincidence between $\mathrm{Mg}$ and $\mathrm{As}$ in ED spectra.

$$
\begin{aligned}
& \text { Phosphuranylite } \mathrm{KCa}\left(\mathrm{H}_{3} \mathrm{O}\right)_{3}\left(\mathrm{UO}_{2}\right)\left[\left(\mathrm{UO}_{2}\right)_{3}\left(\mathrm{PO}_{4}\right)_{2} \mathrm{O}_{2}\right]_{2} \\
& 8 \mathrm{H}_{2} \mathrm{O}
\end{aligned}
$$

It belongs to the most common mineral phases in the recently studied museum (NMCR, MuseumParis) specimens. Phosphuranylite forms compact and powdery yellow aggregates, which surround uraninite strongly affected by supergene alteration (Fig. 7). On rare instanc-

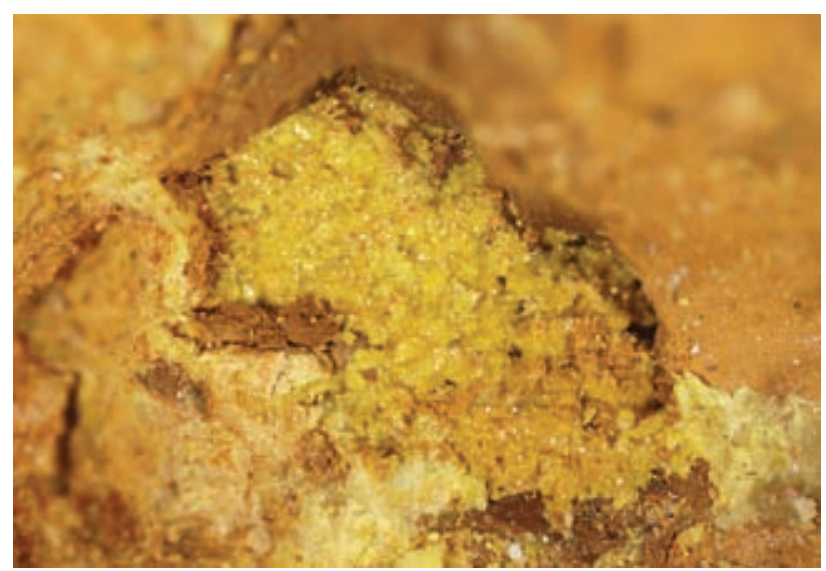

Fig. 7 Yellow aggregates of phosphuranylite on weathered gangue, Horní Slavkov uranium district. Width of the area shown $3 \mathrm{~mm}$. Nicon SMZ1500 microphotography by J. \& E. Sejkora. 
es, the mineral forms crystalline aggregates composed of acicular crystals to $1.5 \mathrm{~mm}$, of a strong yellow orange colour (Fig. 8). Phosphuranylite is accompanied by crystalline aggregates and powdery coatings of autunite and metatorbernite. The refined unit-cell parameters of phosphuranylite (Table 4) are in good agreement with data published by Demartin et al. (1991) and in the diagram by Sejkora et al. (2003) plot in the field corresponding to $\mathrm{Ca}$-dominant members in the series phosphuranylite (Ca) - dewindtite $(\mathrm{Pb})$. A semiquantitative chemical study of phosphuranylite from Horní Slavkov confirmed essential contents of $\mathrm{Ca}, \mathrm{P}$ and $\mathrm{U}$, while $\mathrm{Pb}$ was absent. Potassium content could not be confirmed due to coincidence with $U$ in ED spectra.

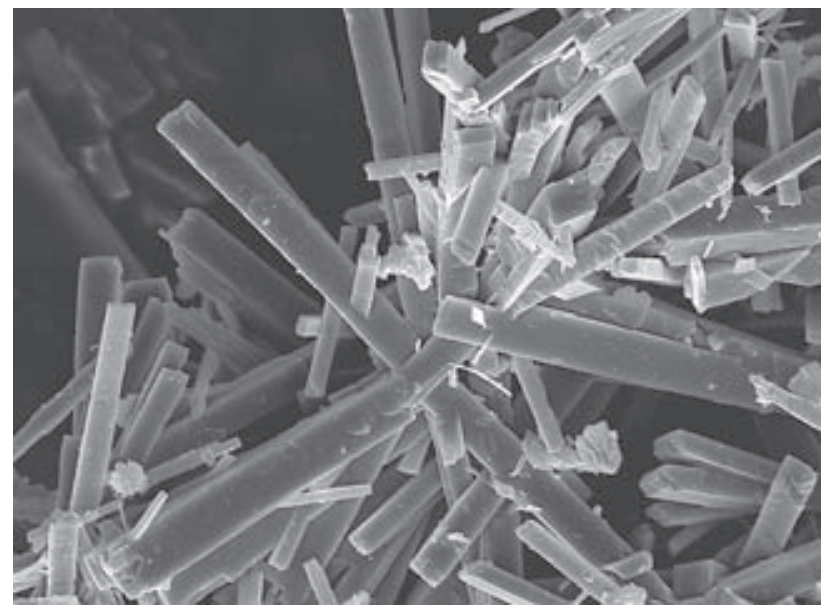

Fig. 8 Acicular crystals of phosphuranylite, Horní Slavkov uranium district. Width of the area shown $60 \mu \mathrm{m}$. SEM photograph by J. Plášil.

Table 4 Unit-cell parameters of phosphuranylite (orthorhombic Cmcm)

\begin{tabular}{|l|lc|}
\hline & this paper & Demartin et al. (1991) \\
\hline $\mathrm{a}[\AA]$ & $15.774(4)$ & $15.778(3)$ \\
$\mathrm{b}[\AA]$ & $13.791(3)$ & $13.769(2)$ \\
$\mathrm{c}[\AA]$ & $17.318(4)$ & $17.330(3)$ \\
$\mathrm{V}\left[\AA^{3}\right]$ & 3767.5 & 3764.9 \\
\hline
\end{tabular}

\section{Rutherfordine $\mathrm{UO}_{2} \mathrm{CO}_{3}$}

Rutherfordine is identified in several museum specimens $(N M C R)$ collected at the Oktyabrskaya vein. It forms yellow to yellow orange crusts penetrating strongly altered uraninite, which is in greater part changed to uranium oxides/hydroxides, designated in the past by the collective name "gummite". These aggregates contain uranophane, phosphuranylite (in crystalline aggregates) and UNK5 (Sejkora et al. 2006). Refined unit-cell parameters of rutherfordine (Table 5) correspond very well to published data for this mineral phase (Finch et al. 1999). Differences observed in intensities of diffraction maxima are probably caused by preferred orientation of microcrystals.
Table 5 Refined unit-cell parameters of rutherfordine (orthorhombic Imm2)

\begin{tabular}{|l|cc|}
\hline & this paper & Finch et al. $(1999)$ \\
\hline $\mathrm{a}[\AA]$ & $4.835(2)$ & $4.840(1)$ \\
$\mathrm{b}[\AA]$ & $9.240(4)$ & $9.273(2)$ \\
$\mathrm{c}[\AA]$ & $4.301(2)$ & $4.298(1)$ \\
$\mathrm{V}\left[\AA^{3}\right]$ & 192.14 & 192.90 \\
\hline
\end{tabular}

\section{Schultenite $\mathrm{Pb}\left(\mathrm{AsO}_{3} \mathrm{OH}\right)$}

Schultenite has been found in samples from weathered galena vein with veinlets and inclusions of marcasite, pyrite and arsenopyrite. This material was collected in the shaft No. 8. Schultenite forms very brittle, red brown oval coatings, covering surface of weathered sulphides. The aggregates are up to several $\mathrm{cm}^{2}$ in size. Schultenite is associated with mohrite, kaatialaite, anglesite and secondary siderite. The mineral is identified only by XRD study due to its occurrence in mixtures with other minerals.

\section{Siderite $\mathrm{FeCO}_{3}$}

It forms grey brown brittle coating and crusts with some imperfect and corroded siderite crystals, deposited on galena crystals. Siderite aggregates are up to $5 \mathrm{~mm}$ long. Samples were collected at the shaft No. 8. The mineral is identified by X-ray powder diffraction.

Soddyite $\left(\mathrm{UO}_{2}\right)_{2} \mathrm{SiO}_{4} \cdot 2 \mathrm{H}_{2} \mathrm{O}$

Dubinkina (1947) described soddyite from the vein system Barbora, encountered in the shaft No. 21 (18 m level) and No. 37 (46 m level). It forms light coloured earthy aggregates replacing weathered uraninite in association with massive cuprosklodowskite aggregates and disseminated minute tabular crystals of zeunerite and uranospinite. Weathered uraninite veins have always strongly limonitized rims. The vein shows a strong fluorescence in the UV light. The presence of soddyite has not been confirmed by the present study.

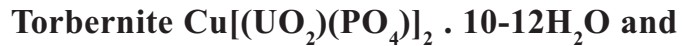 metatorbernite $\mathrm{Cu}\left[\left(\mathrm{UO}_{2}\right)\left(\mathrm{PO}_{4}\right)\right]_{2} \cdot 8 \mathrm{H}_{2} \mathrm{O}$}

Dubinkina (1947) described torbernite from near-surface parts of the uranium veins. The samples were collected during sinking the shafts Nos 1 and 2, exposing the vein Zdař Bůh. Torbernite occurs in association with bassetite and autunite. Another occurrence was described (Dubinkina 1947) from the vein system Barbora. This mineral forms minute tabular crystals on limonitized parts of the uranium vein. Torbernite from this deposit contains substantial As; crystals are often strongly corroded.

In the course of the present study of museum specimens (NMCR, MuseumParis) only metatorbernite has been identified, while the presence of the fully hydrated phase (torbernite) is not indicated. It is probable that de- 
hydration of the original torbernite has taken place during a prolonged storage of the specimens or during sample preparation for X-ray analysis. Metatorbernite forms non-transparent green tabular crystals with mat surface, up to $5 \mathrm{~mm}$ long, and abundant crystalline coatings or crusts. It is associated with autunite and often with uranophane and phosphuranylite. The refined unit-cell parameters (Table 6) are in good agreement with published data.

Table 6 Unit-cell parameters of metatorbernite (tetragonal $P 4 / n$ )

\begin{tabular}{|l|cc|}
\hline & this paper & Locock - Burns (2003) \\
\hline $\mathrm{a}[\AA]$ & $6.9705(7)$ & $6.9756(5)$ \\
$\mathrm{c}[\AA]$ & $17.3464(8)$ & $17.349(2)$ \\
$\mathrm{V}\left[\AA^{3}\right]$ & 842.8 & $844.2(1)$ \\
\hline
\end{tabular}

\section{Uranophane $\mathrm{Ca}\left[\left(\mathrm{UO}_{2}\right)\left(\mathrm{SiO}_{3} \mathrm{OH}\right)\right]_{2} \cdot 5 \mathrm{H}_{2} \mathrm{O}$}

In newly studied museum specimens (NMCR, MuseumParis) uranophane forms relatively abundant compact aggregates of light yellow or yellow colour, up to several cm long (Fig. 9). These aggregates are often intergrown with gangue affected by supergene alteration, consisting mainly of a dark brown amorphous phase with a glassy to greasy lustre, formed by alteration of uraninite. Metatorbernite often accompanies uranophane, sometimes in mutual intergrowth structures. At some specimens, uranophane shows an intimate intergrowth with nováčekite and local zeunerite. The refined unit-cell parameters for

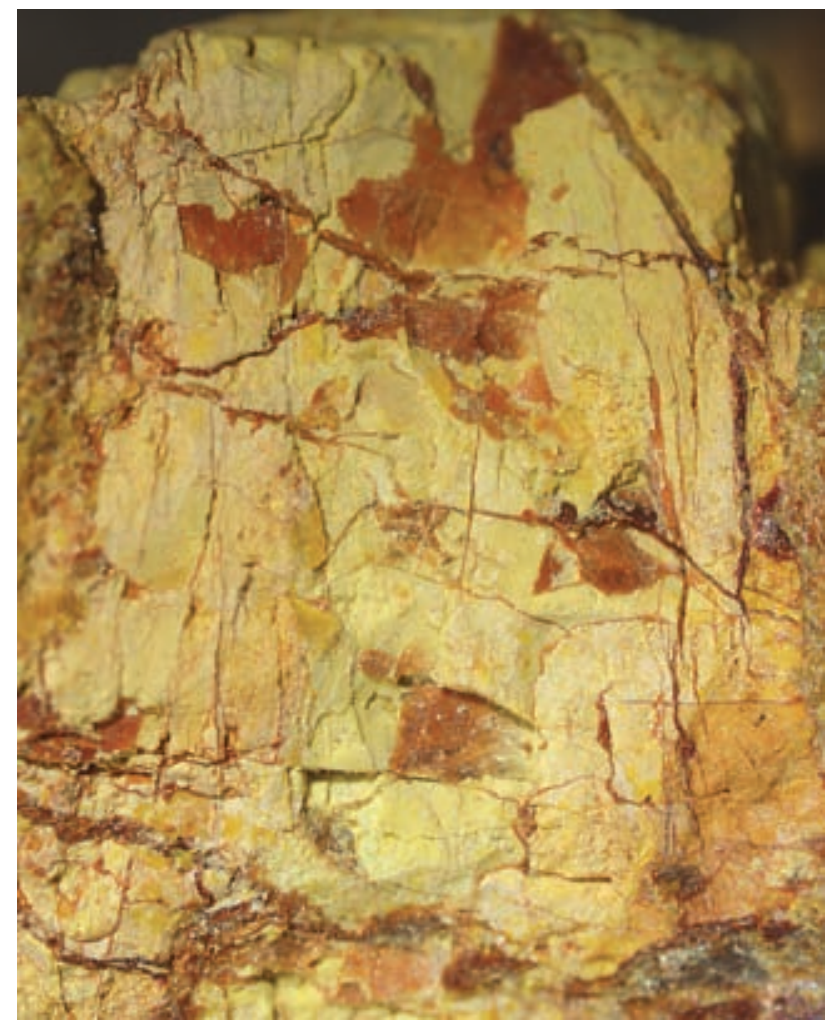

Fig. 9 Yellow aggregates of uranophane in weathered gangue. Horní Slavkov uranium district. Width of the area shown $6 \mathrm{~mm}$. Nicon SMZ1500 microphotography by J. \& E. Sejkora. uranophane (Table 7) are in good agreement with published data.

Table 7 Unit-cell parameters of uranophane (monoclinic $P 2_{1}$ )

\begin{tabular}{|l|cc|}
\hline & this paper & Ginderow (1988) \\
\hline $\mathrm{a}[\AA]$ & $15.904(2)$ & $15.909(6)$ \\
$\mathrm{b}[\AA]$ & $7.0026(9)$ & $7.002(3)$ \\
$\mathrm{c}[\AA]$ & $6.6538(7)$ & $6.665(3)$ \\
$\mathrm{B}\left[{ }^{\circ}\right]$ & $97.224(9)$ & $97.27(4)$ \\
$\mathrm{V}\left[\AA^{3}\right]$ & 735.17 & 736.5 \\
\hline
\end{tabular}

\section{Uranophane- $\mathrm{B} \mathrm{Ca}\left[\left(\mathrm{UO}_{2}\right)\left(\mathrm{SiO}_{3} \mathrm{OH}\right)\right]_{2} \cdot 5 \mathrm{H}_{2} \mathrm{O}$}

Dubinkina (1947) described from the Oktyabrskaya vein a finely acicular silicate of $\mathrm{Ca}$ and $\mathrm{U}$, megascopically similar to uranophane, but showing different optical properties. This may suggest that the mineral is uranophane- $\beta$. It is deposited on weakly weathered uraninite, in association with uranospinite, torbernite and autunite. The presence of uranophane- $\beta$ has not been confirmed in the course of the present study.

\section{Uranospinite $\mathrm{Ca}\left[\left(\mathrm{UO}_{2}\right)\left(\mathrm{AsO}_{4}\right)\right]_{2} \cdot \mathbf{1 0 H}_{2} \mathrm{O}$}

Dubinkina (1947) described uranospinite from the vein system Barbora. This mineral forms minute tabular crystals on weathered and limonitized parts of the veins. Uranospinite from this occurrence contains substantial phosphorus. In the course of the present study, uranospinite occurrence is not unanimously identified. Some powder $\mathrm{X}$-ray diffraction patterns indicate possible uranospinite and sodium uranospinite as a component of fine-grained aggregates of uranyl arsenates. However, these indications could not be confirmed by semiquantitative microprobe spot analyses.

\section{Zeunerite $\mathrm{Cu}\left[\left(\mathrm{UO}_{2}\right)\left(\mathrm{AsO}_{4}\right)\right]_{2} \cdot \mathbf{1 2 H}_{2} \mathrm{O}$}

Dubinkina (1947) described zeunerite from the vein system Barbora as minute tabular crystals on weathered and limonitized parts of the veins. Zeunerite contains substantial phosphorus. In the course of the present study zeunerite is identified in museum specimens (NMCR, MuseumParis). The mineral forms minute thin tabular crystals to $50 \mu \mathrm{m}$ of a bright green colour. It composes crystalline crusts contaning zeunerite intimately intergrown with nováčekite, uranophane and probable uranospinite. Alternatively, zeunerite occurs in association with cuprosklodowskite in green to yellow green powdery or finely crystalline coatings. The refined unit-cell parameters for zeunerite (Table 8 ) are in very good agreement with pub-

Table 8 Unit-cell parameters of zeunerite (tetragonal P4/nnc)

\begin{tabular}{|l|cc|}
\hline & this paper & Locock - Burns (2003) \\
\hline $\mathrm{a}[\AA]$ & $7.1782(5)$ & $7.1797(3)$ \\
$\mathrm{c}[\AA]$ & $20.860(2)$ & $20.857(1)$ \\
$\mathrm{V}\left[\AA^{3}\right]$ & 1074.9 & $1075.1(1)$ \\
\hline
\end{tabular}


lished data and do not indicate a presence of isomorphous $\mathrm{P}$ in the studied sample. The semiquantitative study of chemical composition in homogeneous parts of tabular crystals proved $\mathrm{U}, \mathrm{As}$ and $\mathrm{Cu}$ as substantial elements. Local inhomogenities containing $\mathrm{Ca}$ and $\mathrm{Si}$ are caused by uranophane admixture.

\section{Interpretation of supergene mineralization in the Horní Slavkov uranium ore district}

The present study of available specimens and the data presented by Dubinkina (1947) give evidence on supergene mineralization in several types of environment, featuring different physical-chemical characteristics.

Weathering of primary uraninite under conditions of supergene zone in-situ (at a depth of 15 to $50 \mathrm{~m}$ below the present surface - Dubinkina 1947) resulted in formation of black earthy hydrated uranium oxides or amorphous brown compact $\mathrm{Pb}$-U hydroxides ("gummite-type" mineral phases). Additional supergene alteration of these aggregates followed two distinct lines of evolution, depending on local conditions:

a) associations with predominant oxides, uranyl silicates (and less common uranyl phosphates) - compreignacite, uranophane, phosphuranylite, plus possible soddyite and uranophane- $\beta$ reported by Dubinkina (1947). Only after crystallization of these minerals started formation of the association of cuprosklodowskite and uranyl phosphates/arsenates (autunite, torbernite, zeunerite and nováčekite);

b) association with predominating uranyl phosphates and uranyl arsenates - autunite, torbernite, zeunerite and nováčekite, which formed both in close proximity of older hydrated uranium oxides and primary uraninite, and along fractures in remote parts of the vein filling. The latter case indicates a good mobility of uranyl arsenate/phosphate ions in acidic environment of the supergene zone and at the presence of arsenic-rich primary minerals.

Partial replacement of autunite by the youngest bassetite, partial dissolution of uranyl phosphates (indicated by corroded crystals of torbernite) and deposition of abundant hydrated oxy-hydroxides of $\mathrm{Fe}^{3+}$ ("limonite") took place in the last evolution stage of supergene mineralization in both described paragenetic groups. Dehydration of autunite to meta-autunite and torbernite to metatorbernite belong to recent processes and it took place in part after deposition of specimens in collections.

Additional association of supergene minerals formed in the process of (sub)-recent weathering of ore minerals deposited in dumps on the land surface. The association of anglesite, mohrite, kaatialaite, schultenite and siderite resulted from alteration of galena and associated sulfides; annabergite and arsenolite formed from native As and nickelskutterudite.

Interesting is a museum specimen of relatively fresh uraninite, collected in the course of mining, which carries abundant liebigite aggregates. Rutherfordine is an- other mineral present in these complex aggregates. These occurrences of rather easily soluble uranylcarbonates indicate that mine adits in the Horní Slavkov uranium district possibly carried a (sub)-recent supergene mineralization comparable to that described from Jáchymov (Ondruš et al. 1997 and 2003).

Acknowledgements. The present authors thank PierreJacques Chiappero, Muséum National d'Histoire Naturelle of Paris, for his co-operation in preparation of this article. Our thanks also go to Jaromír Tvrdý, GP Karlovy Vary, Jiří Čejka, Roudnice nad Labem, Jiř́i Litochleb, National Museum, Prague and Stanislav Vrána, Czech Geological Survey, Prague. Our thanks are also due to Oldřich Fatka, Charles University, for kindly providing access to electron scanning microscope (SEM photography) and also to Martin Mazuch for his help. Michal Hušák (Institute of chemical technology, Prague), provided access to data processing with the High Score Plus program. This project received financial support from the Ministry of Culture of the Czech Republic (Project MK00002327201) a Granting Agency of the Czech Republic (Grant No. 205/03/D004).

Submitted May 24, 2006

\section{References}

Beran, P. et al. (2001): The mining town Horní Slavkov. - Published by the Horní Slavkov Town Council in co-operation with the Regional Museum Sokolov, 415 pp., (in Czech).

Burnham, Ch. W. (1962): Lattice constant refinement. - Carnegie Inst. Washington Year Book 61: 132-135.

Burns, C. P. (1998): The structure of compreignacite, $\mathrm{K}_{2}\left[\left(\mathrm{UO}_{2}\right)_{3} \mathrm{O}_{2}(\mathrm{OH})_{3}\right]_{2}$ $\left(\mathrm{H}_{2} \mathrm{O}\right)_{7}$. - Can. Mineral. 36: 1061-1067.

Demartin, F. - Diella, V. - Donzelli, S. - Gramaccioli, C. M. - Pilati, T. (1991): The importance of accurate crystal structure determination of uranium minerals. I. Phosphuranylite $\mathrm{KCa}\left(\mathrm{H}_{3} \mathrm{O}\right)_{3}\left(\mathrm{UO}_{2}\right)_{7}\left(\mathrm{PO}_{4}\right)_{4}$ $\mathrm{O}_{4} \cdot 8 \mathrm{H}_{2} \mathrm{O}$. - Acta Crystallogr. B47: 439-466.

Dubinkina, R. P. (1947): Mineralogical characteristics of localities in "Geological-Industrial report for 1947 year”. - Unpublished paper, ÚSVTRS, 23I, 1948, Příbram, (in Russian).

Dymkov, Ju. M. - Bojcov, V. E. - Preobraženskij, A. N. - Ivanova, O. A. (1986): Ningoyite from hydrothermal veins of Horní Slavkov. - Mineral. Zhurnal, 8: 34-43. (in Russian).

Finch, R. J.-Cooper, M. A. - Hawthorne, F. C. (1999): Refinement of the crystal structure of rutherfordine. - Can. Mineral., 37: 929-938.

Ginderow, D. (1988): Structure de l'uranophane alpha, $\mathrm{Ca}\left(\mathrm{UO}_{2}\right)_{2}$ $\left(\mathrm{SiO}_{3} \mathrm{OH}\right)_{2} .5 \mathrm{H}_{2} \mathrm{O} .-$ Acta Crystallogr., C44: 421-424.

Kominek, J. - Chrt, J. - Landa, O. (1994): Uranium mineralization in the western Krušné hory Mts. (Erzgebirge) and the Slavkovský les region, Czech Republic. - Mineral Deposits, Monograph Series, 31, 209-230.

Locock, A. J. - Burns, C. P. (2003): Crystal structures and synthesis of the copper dominant members of the autunite and metaautunite group: torbernite, zeunerite, metatorbernite and metazeunerite. Can. Mineral., 44: 489-502.

Mereiter, K. (1982): The crystal structure of liebigite, $\mathrm{Ca}_{2} \mathrm{UO}_{2}\left(\mathrm{CO}_{3}\right)_{3} \cdot \sim 11 \mathrm{H}_{2} \mathrm{O}$. - Tschermaks Mineral. Petrogr. Mitt., 30: 277-288.

Ondruš, $P$. (1993): ZDS - A computer program for analysis of X-ray powder diffraction patterns. - Materials Science Forum, 133-136: 297300, EPDIC-2, Enchede.

Ondruš, P. - Skála, R. (1997): New quasi-empirical channel Search/Match algorithm for ICDD PDF2 Database: A tool for qualitative phase analysis integrated in the ZDS-System software package for X-ray powder 
diffraction analysis - Fifth European Powder Diffraction Conference EPDIC-5, 193, Parma.

Ondruš, P. - Veselovský, F. - Gabašová A. - Drábek, M., - Doběs, P. Malý, K. - Hloušek, J. - Sejkora, J. (2003): Ore-forming processes and mineral parageneses of the Jáchymov ore district. - J. Czech Geol. Soc., 48: 157-192.

Ondruš, P. - Veselovský, F. - Hloušek, J. (1997): A review of mineral associations and paragenetic groups of secondary minerals of the Jáchymov (Joachimsthal) ore district. - J. Czech Geol. Soc., 42: 109-114.

Rosenzweig, A. - Ryan, R. S. (1975) Refinement of the crystal structure of cuprosklodowskite, $\mathrm{Cu}\left[\left(\mathrm{UO}_{2}\right)_{2}\left(\mathrm{SiO}_{3} \mathrm{OH}\right)_{2}\right] .6 \mathrm{H}_{2} \mathrm{O}$. - Amer. Mineral., 60: 448-453.
Sejkora, J. - Čejka, J. - Pauliš, P. (2003): Rare lead uranyl phosphate dewindtite from the uranium occurrence Rýžoviště near Harrachov (Krkonoše Mts.), Bohemia, Czech Republic. - Bull. mineral.-petrolog. Odd. Nár. Muz. (Praha), 11, 177-183, (in Czech).

Sejkora, J. - Škoda, R. - Ondruš, P. (2006d): New naturally occurring mineral phases from the area Krásno - Horní Slavkov, western Bohemia, Czech Republic. - J. Czech Geol. Soc., 51: 159188

Tomíček, R. (2000): Exploitation of uranium at Horní Slavkov. - Regional museum Sokolov, Sokolov, 294 pp., (in Czech).

Veselý, T. (1986): The uranium deposit Horní Slavkov. - Geol. Hydrometal. Uran., 10: 5-44, (in Czech).

\section{Supergenní minerály uranového rudního revíru Horní Slavkov, Česká republika}

Článek podává souhrn známých i nově zjištěných poznatků o supergenních minerálech uranového rudního revíru Horní Slavkov (Česká republika). Na základě mineralogického výzkumu byly potvrzeny výskyty anglesitu, annabergitu, arsenolitu, autunitu, carnotitu, compreignacitu, cuprosklodowskitu, kaatialaitu, liebigitu, meta-autunitu, metanováčekitu, metatorbernitu, mohritu, nováčekitu, phosphuranylitu, rutherfordinu, schultenitu, sideritu, torbernitu, uranofánu a zeuneritu a dále nepojmenované fáze UNK5. Dř́ive uváděné výskyty bassetitu, soddyitu, uranofánu-ß a uranospinitu nebyly v rámci nového výzkumu jednoznačně ověřeny. Součástí článku je i interpretace vzniku supergenní mineralizace v popisované oblasti. 